\title{
Popular perceptions of Galileo
}

\author{
Dava Sobel \\ Discover Magazine \\ USA \\ email: ds23@optonline.net
}

\begin{abstract}
Among the most persistent popular misperceptions of Galileo is the image of an irreligious scientist who opposed the Catholic Church and was therefore convicted of heresywas even excommunicated, according to some accounts, and denied Christian burial. In fact, Galileo considered himself a good Catholic. He accepted the Bible as the true word of God on matters pertaining to salvation, but insisted Scripture did not teach astronomy. Emboldened by his discovery of the Medicean Moons, he took a stand on Biblical exegesis that has since become the official Church position.
\end{abstract}

Keywords. Science and faith, astronomy and the Bible, Index of Prohibited Books, blindness.

Popular perceptions and misperceptions about Galileo abound. I will not try to list all of them here, but rather focus on the one that is the most problematic. Because Galileo helped unfold the true nature of the universe, in apparent contradiction to the Bible, his story has come to symbolize the struggle of science against faith. This is the most enduring myth about Galileo: the idea that he was a thoroughly modern - and irreligious scientist, who clashed with a Church blind to reason.

I think the International year of Astronomy has finally convinced the world that Galileo did not invent the telescope. And events of this year have helped thousands, if not millions of people see the things he saw, through an instrument that had been little more than a toy before he improved it. His development of the telescope changed astronomy almost

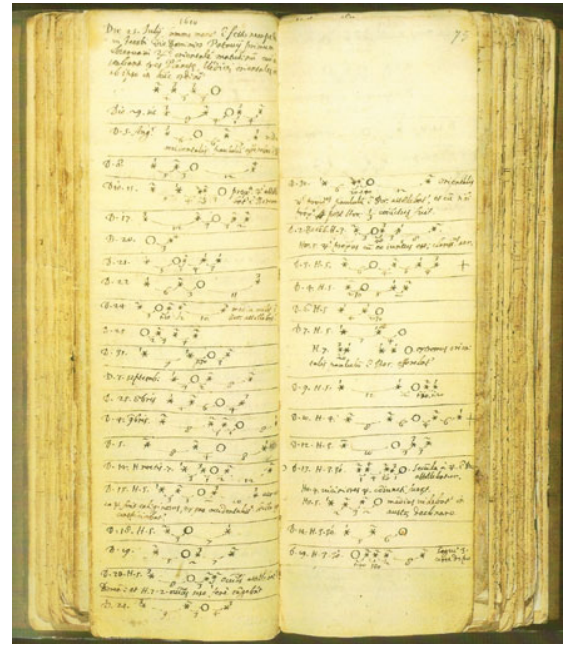

Figure 1. Galileo's record of his continuing observations of the Medicean Moons through summer and fall of 1610. His assessments of the angular distances separating the bodies from one another stand up to modern scrutiny. 
overnight from a science of knowing the positions of bodies, to a science that could discover their composition.

Since I'm talking about Galileo the man, I must point out that there are two big anniversaries to be recognized this week: the discovery of the Medicean Moons, of course, but also Galileo's death, during the night of January 8, 1642.

He discovered the moons while he was a professor of mathematics, here, in this university-although, as you may know, he had no university degree himself, having completed his mathematical studies with private tutors. By this age, he was also the father of two daughters and a son, all born in this city, with baptismal certificates filed in the local parish registry of San Lorenzo. Galileo had met their mother, Marina Gamba, in Venice, and brought her to Padova, though they lived in separate houses, and he never married her.

During his eighteen years here, which he called the happiest of his life, Galileo had many friends, including the Venetian friar Paolo Sarpi. He and Galileo regularly exchanged ideas about physics and astronomy. Sarpi actually beat Galileo to a correct interpretation of the phenomenon of Earth shine. (Leonardo, the first to figure it out, did not publish. Kepler did publish an explanation in 1604, attributing credit to Maestlin, but Sarpi stated the true cause in a notebook entry from 1588.)

You may recall that the reigning pope of this period, Paul V, took action against the Republic of Venice in 1606. He excommunicated the entire Venetian senate, and placed the Veneto under an interdict. This meant that the clergy were prohibited from offering the mass or administering the sacraments. Galileo's youngest child, the boy, was born that summer, but he was baptized anyway, because Sarpi had convinced the clergy to ignore the Interdict, on the grounds that it was a political act and an abuse of power. At the end of one year, in April 1607, the Interdict was rescinded. Soon after that, assassins made an attempt on Sarpi's life, but he survived it. This was a good thing for us, because it was again Sarpi who, in 1608, told Galileo the interesting reports he had heard about a new instrument that could make faraway objects appear close and large.

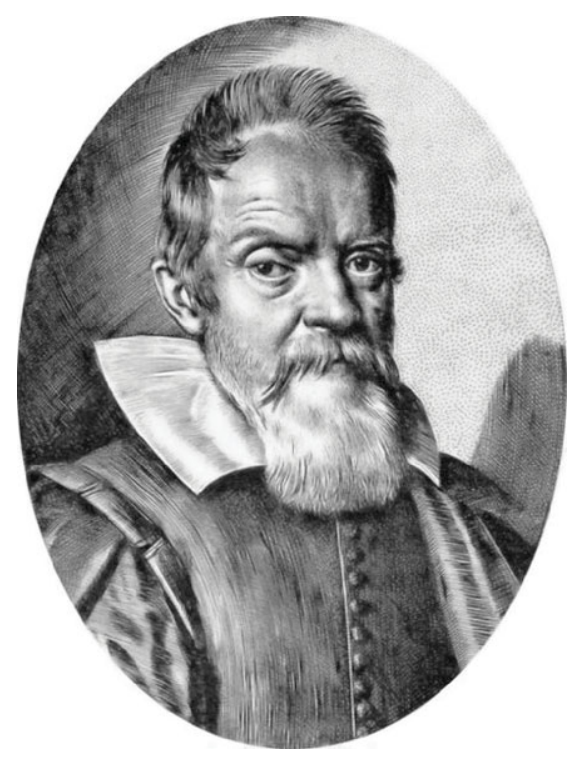

Figure 2. Engraving of Galileo at age 60, based on Ottavio Leoni's portrait in chalk, 1624. The downward cast of his right eye suggests a diagnosis for one of the disease conditions affecting his vision. 
Although several of Galileo's contemporaries also turned telescopes to the sky, he was the first to conduct systematic observations of other worlds, to draw conclusions about their substance and structure, and to publish his findings. These appeared in an explosive little best-seller called Sidereus Nuncius, a title translated as either The Starry Messenger or The Starry Message, which was printed in Venice on March 13, 1610. And sold out within one week. (A new translation is just out from Bill Shea.)

It is known that Galileo had read and accepted the ideas of Copernicus years before he began his telescopic investigations-at least as early as 1597, when, in a letter to Kepler, he declared himself a timid "Copernican." But it took his discoveries to convince him that the Earth really did revolve around the Sun, as one of the planets. And that he could at last speak out publicly about these convictions.

Like Galileo, Copernicus was a good Catholic, who not only worked for the Church in Poland, but dedicated his famous book, On the Revolutions of the Heavenly Spheres, to the pope of his time, Paul III.

What separates Copernicus from Galileo is a lapse of years, during which time an ecumenical council took place at Trent. It began in 1545, two years after Copernicus's death, and concluded in 1563, the year before Galileo was born. Its mission was to contain the Protestant heresy. And one of the outcomes of the Council was a formal and strict position on the interpretation of Holy Scripture. Whereas Martin Luther advocated every man's right to a personal take on Bible reading, the Catholic Church insisted that all the faithful adhere to the official interpretation promulgated by the holy fathers.

Copernicus had been well aware that his theory was open to attack by persons he called "babblers" who would twist and "badly distort some passage of Scripture to their purpose." It was for that reason he dedicated the book to Paul III, whom he credited with understanding that "Astronomy is written for astronomers." While Copernicus's book was in press, he suffered a fatal stroke, and never had to answer to critics. He also remained unaware that the proofreader, who was a Protestant minister, had inserted a cautionary note to readers, stipulating that the heliocentric theory was strictly for the purpose of mathematical calculation, and had no counterpart in reality. "Let no one expect anything certain from astronomy," this statement warned, "lest he... depart from this study a greater fool than when he entered it."

But Galileo's discoveries were not purely mathematical. He was seeing real stars in the heavens that had been invisible before his improvements to the telescope. In the constellation of Orion alone, he estimated several hundred more stars than had been listed in any of the existing star catalogs.

Galileo's observations of the moons of Jupiter were extraordinary, not only for their novelty and the care with which he recorded them, but because they provided evidence for what Copernicus had merely intuited. The Earth was not the center of all celestial motion. There were bodies in orbit around Jupiter. And furthermore, if Jupiter could move through the heavenly ether with all four moons in tow, then what was to stop the earth, which commanded only one moon, from proceeding on its own orbital course around the Sun?

And what was Galileo's response to his own monumental discovery? A prayer of thanksgiving: "I render infinite thanks to God for being so kind as to make me alone the first observer of marvels kept hidden in obscurity for all previous centuries."

For Galileo, there was nothing irreligious about these discoveries or their implications.

In the spring of 1611, Galileo traveled to Rome to defend the truth of his discoveries. Because of the difficulty of producing a good telescope, others had trouble replicating his results, and therefore doubted his claims. 
During this 1611 visit, he won the unequivocal endorsement of the Jesuits at the Roman College. Both he and they were committed to figuring out the periods of the Medicean Moons, an extremely arduous project that depended on amassing reams of good data. (The moons seemed to promise a reliable way to determine longitude at sea, which, in Galileo's time, was already a problem of international importance-and one that would not be solved until well into the following century.)

One of the Roman Cardinals taking an interest in Galileo's telescopic findings was the "hammer of the heretics," Roberto Bellarmino, who was attached to the Congregation of the Holy Office of the Inquisition. He specifically requested his fellow Jesuits at the Roman College to evaluate Galileo's work. There were various reasons to question the texture of the Moon's surface, and the nature of the strange appendages that seemed to sprout from Saturn. No astronomer, however, could doubt the reality of the Medicean Moons. Their existence and motion were incontrovertible, but... Did they really offer proof of the Earth's motion? That wasn't nearly so certain.

Interestingly, Cardinal Bellarmino had been the chief spokesman for Rome in the flap with Sarpi over the Interdict.

And Cardinal Bellarmino was well acquainted with the ideas of Copernicus. In fact, scarcely a decade before Galileo's discoveries, Bellarmino had served as a cardinal inquisitor in the trial of a famous heretic who also embraced the heliocentric model.

When the Dominican priest Giordano Bruno took up the Copernican idea, he extended it into an infinite cosmos, where every star was a sun surrounded by its own retinue of planets. This raised the question of life on those other worlds, and salvation for their inhabitants. And you begin to realize that Bruno's ideas were indeed heretical. In fact he was excommunicated twice, by the Catholic Church and the Calvinist. He doubted the divinity of Jesus, the virginity of Mary, and the transubstantiation of the Communion wafer into the body of Christ. But popular myth has reduced all of that to his belief in the Copernican idea-as though his story were merely a prequel to Galileo's. People often ask, if the Inquisition condemned Bruno to burn at the stake, then why didn't it do the same to Galileo?

By 1615, Galileo became aware that the Congregation of the Index was about to ban Copernicus's book, and he traveled to Rome again, to try to forestall any such action, which he feared would be disastrous-both for astronomy (Why ban the book NOW, when evidence in support of it accumulates daily?) and also for the Church (If Catholics are prohibited from teaching and studying these subjects, then the Protestants will unravel the universe, and the Church will be embarrassed.). He went to Rome with two powerful arguments: his theory of the tides, and his conviction that the Bible was a book about how to go to Heaven, not how the Heavens go. He never contested the truth of the Bible, believing it to be the Word of God, but he did not think the Holy Spirit would waste time teaching, by means of Scripture, things that an intelligent person could learn about Nature on his own, using his God-given talents, such as vision, intelligence, manual dexterity, speech. What's more, the Bible said hardly anything about astronomy. And in the few places where it mentioned one or another of the heavenly bodies, it spoke metaphorically, or according to the perceptions of the common man, not as a scientific authority. This was Galileo's big mistake. Because how could he, a layman, dare to interpret the Bible?

While Galileo remained in Rome, the Holy Office of the Inquisition met and voted against the motion of the Earth, which they termed "heretical," "foolish," and "absurd." Before this news became public, Pope Paul V chose Cardinal Bellarmino to meet privately with Galileo, in February of 1616, and tell him to drop the subject. Copernicus was put on the Index of Prohibited Books, supposedly "suspended until corrected." But even 
after the requisite corrections were issued in 1620, the book stayed on, still prohibited, until the 1835 edition of the Index.

Galileo did as he was told. He stopped talking about cosmology for seven years. He worked on the longitude problem. He studied poetry and wrote literary criticism. By modifying his telescope, he developed a compound microscope.

A popular misconception holds that Galileo went blind by staring at the Sun to observe its spots, but he was too smart to do that. Besides, the pain would have been excruciating. No, he observed the Sun safely, by letting its image fall through the telescope tube onto a sheet of paper, where he could trace the exact outlines of the solar spots. And while doing that, he discovered the Sun's monthly rotation. One more myth about Galileo's blindness suggests that he might not have gone blind, if only the Church had granted permission for him to seek proper medical attention while he was under house arrest. But, Galileo had a lifelong history of eye ailments, and he lived to an age (78) when blindness can befall almost anyone. An ophthalmologist in England, Peter Watson, has been trying for more than a decade to determine the cause of Galileo's blindness, from reports and also from contemporary portraits. This particular image, an engraving based on a chalk study by Ottavio Leoni in 1624, shows the right eye displaced downward, and a swelling of the forehead on that same side, raising the eyebrow and lowering the lid. It's not a definitive diagnosis, but Watson notes these are symptoms of a condition called frontal sinus mucocoele.

While Galileo was busy keeping quiet, a remarkable thing happened. In 1623, Cardinal Maffeo Barberini, Galileo's longtime acquaintance, was elected Pope Urban VIII. Galileo sensed a significant change in the Roman climate. And he returned to Rome to pay his respects and feel out the new pontiff on a possible reprisal of the subject of the earth's place in the heavens. He wanted to write a book about it. In fact he'd been planning such a book ever since his first published announcement of his discoveries. Their relations were quite cordial at this point, and Urban had long expressed interest in Galileo's work. However, the two men took opposing views of science. Galileo felt that God had created the universe in such a way that humans could figure it out from mathematical clues-that in fact figuring out the universe was humankind's mission on earth. But, from Urban's point of view, the universe would be a pretty puny affair if a mere mortal could figure it out. Much more likely that an Omnipotent Creator would fashion a different set of laws of physics for every individual phenomenon, and no matter how much evidence you gathered for any particular argument, you could not hold God to your argument. In other words, nothing short of Divine Revelation would suit.

As soon as Galileo's big book appeared, in 1632, it caused a furor. And the next time Galileo went to Rome, it was in answer to a summons to stand trial before the Inquisition. The trial resulted in Galileo's abjuration and public humiliation. His book was listed on the Index. He lived out his remaining years under house arrest, but he recovered his spirit sufficiently to continue a few observations and also to write another book, Dialogues Concerning Two New Sciences, which is considered to be his scientific masterpiece, though it isn't nearly as engaging to read as the Dialogue on the Two chief Systems of the World. That title stayed on the Index of Prohibited Books, along with Copernicus, for nearly two centuries.

Galileo is buried in the Church of Santa Croce, in Florence. At the time of his death, the Pope prohibited the Grand Duke from giving Galileo an important funeral oration or an imposing tomb. It took almost one hundred years for his devoted followers to move his remains to the much visited tomb.

Today, the moons that Galileo named for the grand duke of Tuscany are better known as the Galilean satellites of Jupiter-a name that Johannes Kepler gave them in 1610. 
Galileo also has a crater named for him on Earth's Moon, as do Copernicus, Kepler, and even Bruno (on the far side). All moons belongs to science now.

The first direct evidence for the motion of the Earth came when English astronomer James Bradley, around 1730, discovered the aberration of starlight. Not long after that, in 1758, the Church lifted the general ban on teaching the heliocentric theory. But even at that point, certain specific works remained on the Index-including Copernicus's own book, Kepler's Epitome of Copernican Astronomy and Galileo's DIALOGUE - all expressly forbidden until the Index of 1835 .

A little later in the 19th century, more definitive proof came to light regarding the Earth's motion: In Germany in 1838, Friedrich Wilhelm Bessel succeeded in measuring the parallax of the star 61 Cygni, and derived a distance to that star of 6 light-years. The universe was bigger by far than even Newton had imagined. Still more demonstrable proof for the Earth's motion came in the early 1850's, with Foucault's pendulum.

As for the official Church position on science, according to the 1893 Providentissimus Deus of Pope Leo XIII, it is held that the Bible does not aim to teach science. So, at least posthumously, Galileo won the argument.

But by then, at the end of the $19^{t h}$ century, the myth of Galileo as a martyr of science was firmly established. And it may never be dispelled. In popular perception, he is still pitted against the Church. Despite the fact that Pope John Paul II re-opened the Galileo case in the hope of taming its pervasive, divisive power, his public statement in 1992 acknowledged no wrong-doing on the Church's part. Instead, the Pope's statement blamed the theologians of the $17^{\text {th }}$ century for failing to grasp the theological issues at play, and blamed Galileo for misunderstanding the limits of scientific certainty.

I had hoped that one outcome of the IYA might be a truce, in honor of Galileo, between science and religion. For, as his writings clearly show, he had no need to jettison his religious beliefs to perform first-rate science. Nor did Copernicus, nor Kepler, nor Newton.

Even today, there are working scientists who believe in a divine Creator, but they usually don't let on that they do. At least not in the laboratory or the observatory.

\section{References}

Galilei, Galileo, Sidereus Nuncius or A Sidereal Message, Translated from the Latin by William R. Shea. Introduction and Notes by William R. Shea and Tiziana Bascelli, Sagamore Beach, Mass.: Watson, 2009

Galilei, Galileo, Sidereus Nuncius or The Sideral Messenger, Translated with introduction, conclusion and notes by Albert Van Helden, Chicago: University of Chicago, 1989

Sobel, D., Galileo's Daughter: A Historical Memoir of Science, Faith and Love, New York: Walker, 1999 